\title{
Physiological Performance of Rice Seeds Treated to Thiamethoxam and Placed under Storage
}

\author{
Andreia da Siva Almeida ${ }^{*}$, Cristiane Deuner ${ }^{1}$, Carolina Terra Borges ${ }^{1}$, Adilson Jauer ${ }^{2}$, \\ Geri Eduardo Meneghello', Lilian Madruga de Tunes', Francisco Amaral Villela', \\ Paulo Dejalma Zimmer ${ }^{1}$ \\ ${ }^{1}$ PPG em Ciência e Tecnologia de Sementes, Universidade Federal de Pelotas, Pelotas, Brasil \\ ${ }^{2}$ Syngenta Crop Protection, Pelotas, Brasil \\ Email: ${ }^{*}$ andreiasalmeida@yahoo.com.br
}

Received 12 October 2014; revised 15 November 2014; accepted 29 November 2014

Copyright (C) 2014 by authors and Scientific Research Publishing Inc.

This work is licensed under the Creative Commons Attribution International License (CC BY). http://creativecommons.org/licenses/by/4.0/

(c) (i) Open Access

\begin{abstract}
High-yielding crops can only achieve their potential when the appropriate technological tools are applied and weather conditions do not impose restrictions. One such technological tool is the treatment of seeds, in which different products are used and, in some cases, cause little-known effects capable of modifying the plant's metabolism and/or its morphology. The insecticide thiamethoxam alters the plant's physiology and morphology, accelerating its development, thus enhancing its vigor. The objective of this study was to evaluate the influence of thiamethoxam on the physiological performance of rice seeds during storage. The research was conducted in a greenhouse and at the laboratory of the Department of Plant Science, Faculty of Agronomy Eliseu Maciel -UFPel (Federal University of Pelotas). Rice seeds from cultivars INIA Olimar and El Paso L144 were treated to a commercial product containing 350 grams of active ingredient thiamethoxam at doses of $0,100,200,300,400$ and $500 \mathrm{~g}$ per $100 \mathrm{~kg}$ of seed. Seeds were tested for physiological quality immediately after being treated (check treatment) and at 3, 6, 9 and 12 months under storage, through germination test, cold test, accelerated aging and greenhouse emergence test. The concentration range from 200 to $400 \mathrm{~g}$ a.i. $100 \mathrm{~kg}^{-1}$ seed yielded the highest germination and seed vigor values for both rice cultivars during the storage period.
\end{abstract}

\section{Keywords}

Oryza sativa (L.), Bioactivator, Vigor, Seed Viability

\footnotetext{
"Corresponding author.
}

How to cite this paper: da Siva Almeida, A., Deuner, C., Borges, C.T., Jauer, A., Meneghello, G.E., de Tunes, L.M., Villela, F.A. and Zimmer, P.D. (2014) Physiological Performance of Rice Seeds Treated to Thiamethoxam and Placed under Storage. American Journal of Plant Sciences, 5, 3788-3795. http://dx.doi.org/10.4236/ajps.2014.526396 


\section{Introduction}

Rice is considered one of the most important human foods worldwide, holding key economic and social roles. Brazilian produce is estimated to be some 12 million tons, of which over $65 \%$ is grown in the state of Rio Grande do Sul, where average yields go beyond $7000 \mathrm{~kg} \cdot \mathrm{ha}^{-1}$ [1].

High-yielding seed crops not only need favorable climatic conditions, but the use of technological tools, such as seed treatment to support them. Although seed coating with fungicides and insecticides is a long-known technology, it has only been basically evaluated regarding its efficiency on the control of pests and plant diseases. Some of them can exert little known effects upon plants, modifying their morphology as well as their metabolism [2].

The insecticide thiamethoxam is one such product, which according to [3], alters plant morphology and physiology as it is transported within the plant cells, where it activates several physiological reactions such as protein expression. These proteins are responsible for the plant's stress defense reactions, allowing the individual to better confront adverse conditions such as drought, low soil $\mathrm{pH}$, high soil salinity, free radicals, high temperatures, injuries caused by pests, virus attacks and nutrient deficiencies. In addition to these effects, thiamethoxam stimulates faster plant development, resulting in enhanced vigor [4].

[5] described the effect of thiamethoxam on soybean as increasing its vigor, leaf area, root system and providing a more uniform crop stand, which resulted from faster and more uniform seedling emergence.

According to [4], treating rice seeds with thiamethoxam favored their physiological quality, the most efficient range being that of $300 \mathrm{~mL}$ to $400 \mathrm{~mL} \cdot 100 \mathrm{~kg}^{-1}$ seed.

Since seed treatments are performed some time prior to seeding, treated seed lots may be stored for varying periods, during which eventual chemical reactions may damage the seed. [6] reported that some chemical treatments to seeds can adversely affect their performance, especially when high concentrations of the active ingredient are applied. These effects can be enhanced by long storage periods, eventually reducing the seed germination potential. In rice, [7] observed that seeds treated to fungicide and stored for various lengths of time experienced reductions in their germination and vigor values under long term storage, regardless of the environmental conditions. It is thus sensible to search for technologies that will allow the storage of treated seeds without losses in their quality, which will facilitate their management by seed producers as well as by the end consumers, rice growers.

The aim of this work was to evaluate the effects of the insecticide thiamethoxam on the physiological performance of rice seeds during storage.

\section{Material and Methods}

The research was conducted at the Seed Laboratory (LDAS-UFPel) and glasshouse, of the Department of Plant Science, Faculty of Agronomy Eliseu Maciel (FAEM), at the Federal University of Pelotas (UFPel).

Seeds from rice cultivars INIA Olimar El Paso L144 were used at a rate of $4 \mathrm{~kg}$ per treatment and cultivar, with four replicates. The seeds were treated to a commercial product containing 350 grams of a.i. thiamethoxam at doses of $0,100,200,300,400$ and $500 \mathrm{~g} \cdot 100 \mathrm{~kg}^{-1}$ seeds. Immediately after treatment (check) with thiamethoxam, and at periods of 3, 6, 9 and 12 months of storage, seeds were evaluated for their physiological quality through the germination test, with four 50-seed replicates per treatment. The seeds were sown in "Germitest" paper rolls, moistened with distilled water at a ratio of 2.5 times the weight of dry paper and kept in the germination chamber, set at $25^{\circ} \mathrm{C}$. The evaluations were performed according to the Rules for Seed Testing [8] and the results expressed as percentage of normal seedlings. The cold test was assessed through four 100 -seed replicates in "Germitest" paper rolls moistened with distilled water at a ratio of 2.5 times the weight of dry paper. The rolls were placed into plastic bags, sealed with adhesive tape and kept in a refrigerator set at $10^{\circ} \mathrm{C}$ for seven days. After this period, the rolls were transferred to a germination chamber at $25^{\circ} \mathrm{C}$, where they remained for another seven days, as described by [9]. The results were expressed as percentage of normal seedlings. The accelerated aging test was conducted using the method of plastic boxes [10], with seeds distributed in a ingle layer on the screen and the bottom of the box filled with $40 \mathrm{~mL}$ of distilled water. The boxes were then transferred into a BOD growth chamber where they were kept at $42^{\circ} \mathrm{C}$ for 60 hours, according to the recommendations by [11]. After the aging period, four 50 -seed replicates were put into the germination chamber at $25^{\circ} \mathrm{C}$ and the percentage of normal seedlings counted on the fifth day. In the seedling emergence test four 25-seed replicates per treatment were sown in pots in the greenhouse, using soil as substrate. The final count for normal seedlings oc- 
curred at 21 days after sowing, when seedling emergence leveled.

A $6 \times 5$ factorial design (thiamethoxam doses $\times$ storage period) was laid over a completely randomized design with four replicates per rice cultivar. Thiamethoxam effects were analyzed through polynomial regressions using the Winstat 1.0 statistical package [12]. Data for seed quality expressed on a percentage basis was arc-sine transformed prior to analysis [13].

\section{Results and Discussion}

A significant interaction was observed for all the response variables, with the exception of seedling emergence in cv. INIA Olimar, which responded only to the thiamethoxam dose. All the variables available present significance to the interaction, except emerge in greenhouse, that was made the developments, and when there are no significance to the interaction was constructed only one trend line.

Thiamethoxam's maximum efficiency in germination was in the 200 to $400 \mathrm{~g} \cdot 100 \mathrm{~kg}^{-1}$ seed range, followed by a decrease in germination values for the $500 \mathrm{~g} \cdot \mathrm{kg}^{-1}$ dose (Figure 1(a) and Figure 1(b)). A 9\% increase
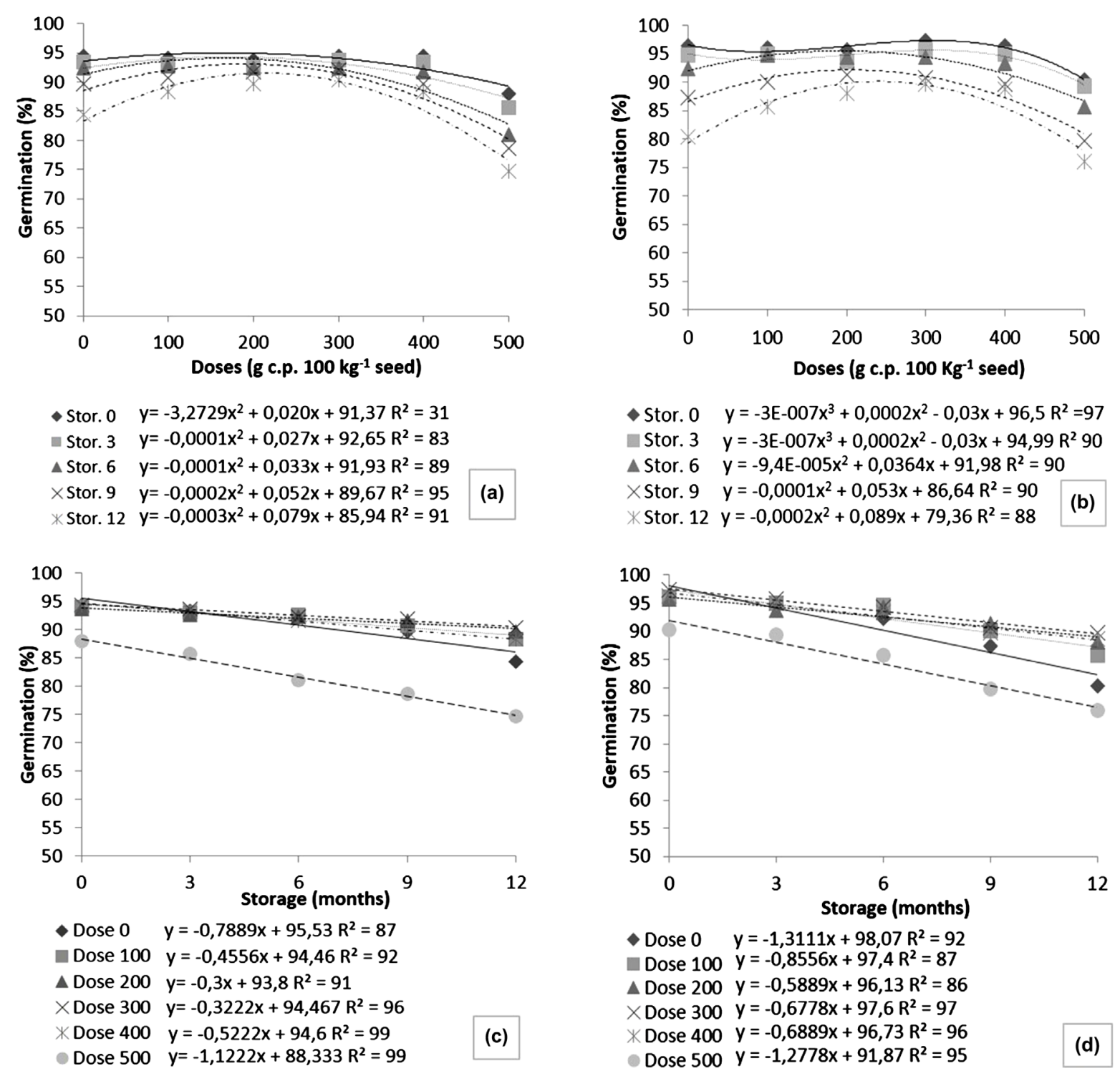

Figure 1. (a) Germination (G) of rice seeds, cultivate INIA Olimar, subjected to different doses of thiamethoxam; (b) G rice seed, cultivate El Paso, subjected to different doses of thiamethoxam; (c) G rice seed, cultivate INIA Olimar, under different storage periods; and (d) G rice seed, cultivate El Paso, under different storage periods. Pelotas, RS, 2014. 
compared to that of the check treatment ( $0 \mathrm{~g}$ thiamethoxam per $100 \mathrm{~kg}$ of seed) on the germination value of seeds from cultivar INIA Olimar was observed at the $300 \mathrm{~g}$ thiamethoxam dose, at the beginning of the storage period (0 months). This result agrees with findings by [14] in carrot seeds, [15] in soybean, and [16] in rice, who observed that thiamethoxam accelerated germination while promoting a faster growth of the embryonic axis. [17] applied doses of 6.2 to $7.0 \mathrm{~mL} \cdot \mathrm{kg}^{-1}$ of Cruiser ${ }^{\circledR} 350 \mathrm{FS}$ to different batches of cotton seeds and observed increased germination relative to untreated seeds in the range from 12 to 14 percentage points, depending on the batch.

Throughout the different storage periods, seed germination values in both cultivars for treatments within the range 0 to $400 \mathrm{~g}$ thiamethoxam remained above the minimum of $80 \%$ required by Brazilian legislation [18] for marketable seed. At the $500 \mathrm{~g}$ thiamethoxam dose rice cultivar INIA Olimar maintained germination values above $80 \%$ up to the 6month storage period, whereas for rice cultivar El Paso L144, the high germination values were recorded up to 9 months of storage (Figure 1(c) and Figure 1(d)). According to [19], the high initial quality of seed lots decreases their rate of decay, if stored under appropriate moisture and temperature conditions.

Cultivar INIA Olimar exhibited a small linear decrease ranging from $4 \%$ to $13 \%$ germination after 12 months of storage, depending on the thiamethoxam dose used (Figure 1(c)). For cv. El Paso L144, this reduction ranged, depending on the thiamethoxam dose, from $7 \%$ to $16 \%$ (Figure 1(d)).

In general, the dose of $500 \mathrm{~g}$ thiamethoxam $100 \mathrm{~kg}^{-1}$ seed showed a slight decrease in seed quality (Figures 1(a)-(d)). According to [6], some chemical treatments applied to seeds tend to generate latent effects, which affect seed performance at increasing doses and may be enhanced by the duration of the storage period.

In the cold test germination increases of $18 \%$ for rice cultivar INIA Olimar and $14 \%$ for cv. El Paso L144, compared to the check treatment, were recorded at the $300 \mathrm{~g} \cdot 100 \mathrm{~kg}^{-1}$ seed dose (Figure 2(a) and Figure 2(b)). For thiamethoxam levels beyond $300 \mathrm{~g} / 100 \mathrm{~kg}^{-1}$ seeds, germination enhancements decreased, as did seed vigor (Figure 2(c) and Figure 2(d)).

[20] observed increased germination rates for the cold test in seeds of bristle oat treated with thiamethoxam, reaching maximum response at a dose of $284 \mathrm{~mL} \cdot 100 \mathrm{~kg}^{-1}$ seed, followed by a decrease at higher doses.

Thiamethoxam application reduced germination decline along the storage period, with the best results for seeds of cv. INIA Olimar at doses of 300 and $400 \mathrm{~g} \cdot 100 \mathrm{~kg}^{-1}$, with a reduction of 2 and 5 percentage points, respectively, whereas for seeds from cv. El Paso L144 the best results were for doses of 200 and $300 \mathrm{~g} \cdot 100 \mathrm{~kg}^{-1}$ seed, for both of which the decrease in germination value was $7 \%$.

Similar results to those produced by the cold test were found for the accelerated aging test, where increases of $18 \%$ to $12 \%$ on the germination values for rice cvs. INIA Olimar and El Paso L144, respectively, were observed compared to the check treatment when treated to thiamethoxam doses of $300 \mathrm{~g} \cdot 100 \mathrm{~kg}^{-1}$ seed (Figure 3).

The evaluation of seed vigor through rate of seedling emergence in the greenhouse showed that for cvs. Olimar and El Paso L144 there was an increase of up to $16 \%$ vigor in the dose effect between 0 and $300 \mathrm{~g}$ thiamethoxam $100 \mathrm{~kg}^{-1}$ seeds (Figure 4(a) and Figure 4(b)). [21] found no change in the vigor and seedling emergence of sunflower seeds treated with thiamethoxam and fipronil.

Seed vigor decreased with length of storage across all thiamethoxam doses, the same trend as that observed for germination. For both rice cultivars the greatest decline in seed vigor occurred for thiamethoxam doses 0 and $100 \mathrm{~g}$ (Figure 4(c) and Figure 4(d)). The variable emergence in greenhouse has no significance to the interaction, that was made only one trend line.

[4] developed work with the same rice cultivars used in this study plus cultivars IRGA BR 410 and BR IRGA 424, observing that the treatment of seeds with thiamethoxam enhanced seed quality, with the best results for doses of 300 to $400 \mathrm{~mL} \cdot 100 \mathrm{~kg}^{-1}$ seed. According to Clavijo (2008), thiamethoxam enhances the vigor of rice seeds regardless of cultivar and environment, also increasing the germination speed, emergence and biomass production.

In rice grown at low temperatures, [22] also found a positive effect on seed quality from thiamethoxam treatment, with doses in the range of 100 to $200 \mathrm{~mL}$ being the most effective at temperatures between $13^{\circ} \mathrm{C}$ and $25^{\circ} \mathrm{C}$.

Working with low quality rice seeds, [23] observed that treatment with thiamethoxam and rhizobacteria enhanced their physiological potential, regardless of their low initial status. In cotton, Lauxen et al. (2010) observed that the quality of seeds treated with thiamethoxam was enhanced at doses ranging from 0.175 to $0.245 \mathrm{~g}$ a.i. $L^{-1}$. 


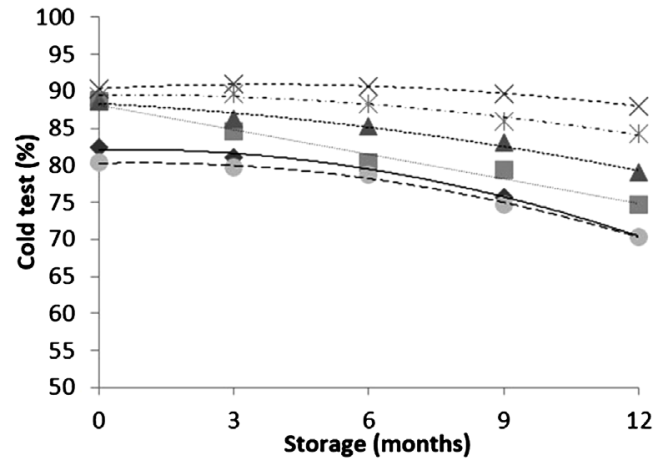

- Dose $0 \quad y=-0,0899 x^{2}+0,1015 x+82,11 R^{2}=99$

Dose $100 y=-1,1111 x+88,2 R^{2}=97$

$\triangle$ Dose $200 \quad y=-0,037 x^{2}-0,3111 x+88,33 R^{2}=98$

$\times$ Dose $300 \quad y=-0,0423 x^{2}+0,307 x+90,37 R^{2}=100$

* Dose $400 \quad y=-0,0397 x^{2}+0,020 x+89,55 R^{2}=97 \quad$ (a)

- Dose $500 y=-0,082 x^{2}+0,150 x+80,25 R^{2}=99$

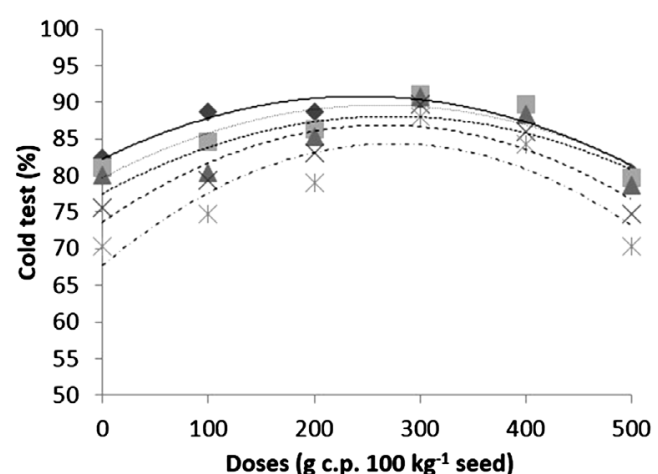

- Stor. $0 \quad y=-0,0001 x^{2}+0,063 x+81,56 R^{2}=91$

Stor. $3 y=-0,0002 x^{2}+0,089 x+82,06 R^{2}=85$

$\Delta$ Stor. $6 \quad y=-0,0003 x^{2}+0,105 x+79,46 R^{2}=95$

$\times$ Stor. $9 \quad y=-0,0003 x^{2}+0,122 x+76,60 R^{2}=91$

* Stor. $12 y=-0,0004 x^{2}+0,152 x+71,28 R^{2}=90$

(c)
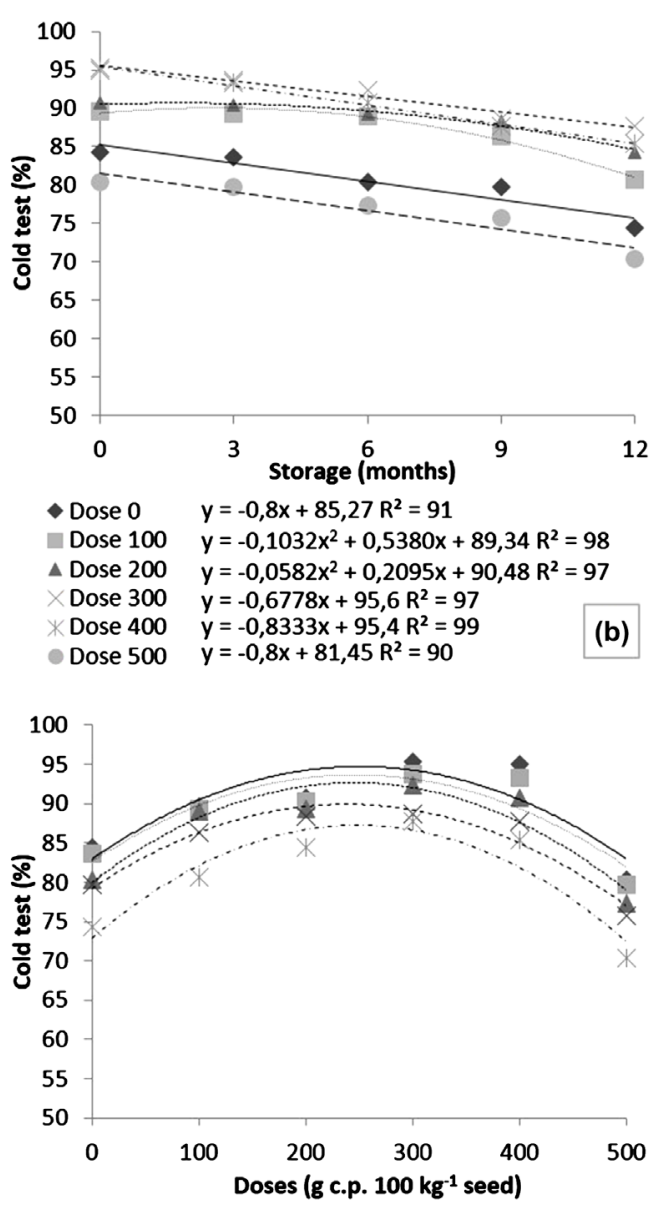

४ Stor. $0 \quad y=-0,0002 x^{2}+0,094 x+82,90 R^{2}=75$

Stor. $3 \quad y=-0,0002 x^{2}+0,0891 x+82,60 R^{2}=80$

$\triangle$ Stor. $6 \quad y=-0,0002 x^{2}+0,1031 x+79,98 R^{2}=89$

$\times$ Stor. $9 \quad y=-0,0002 x^{2}+0,089 x+79,24 R^{2}=92$

* Stor. $12 y=-0,0002 x^{2}+0,115 x+72,86 R^{2}=88$

(d)

Figure 2. (a) Cold test (CT) of rice seeds, cultivate INIA Olimar, subjected to different doses of thiamethoxam; (b) CT seeds of rice cultivate El Paso, subjected to different doses of thiamethoxam; (c) CT seeds of rice cultivate INIA Olimar, under different storage periods; and (d) CT seeds of rice cultivate El Paso, under different storage periods. Pelotas, RS, 2014.
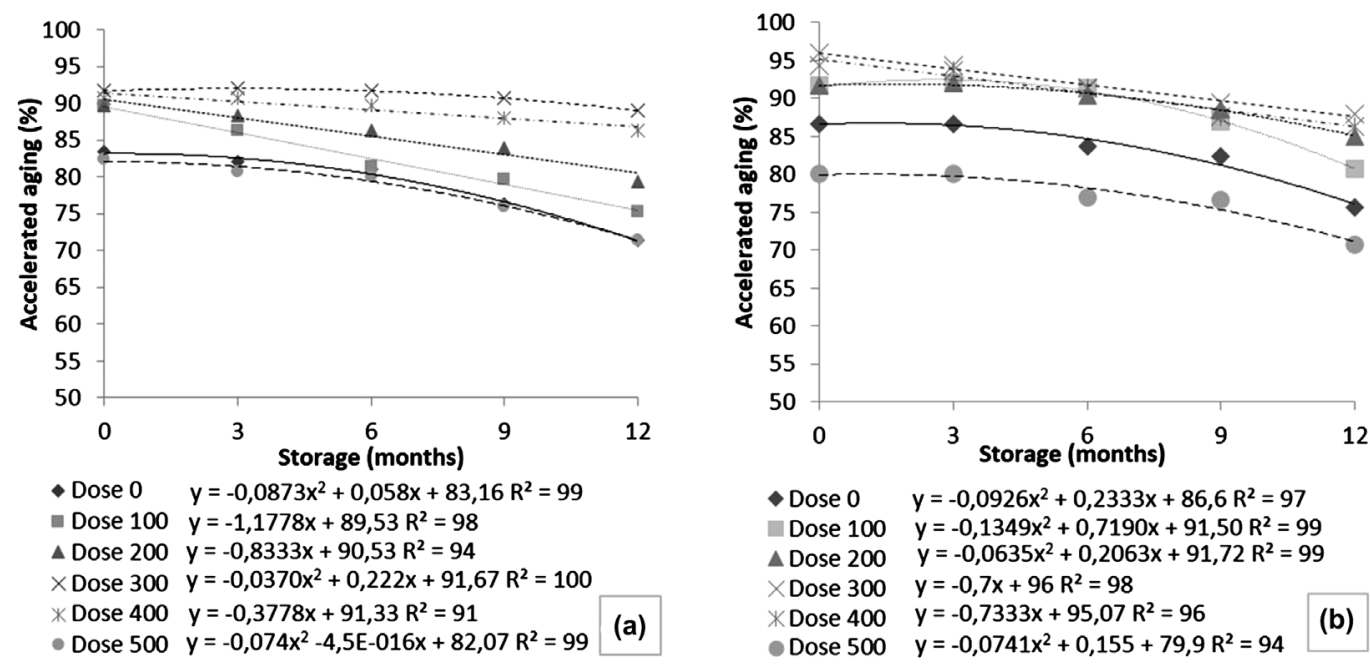

- Dose $0 \quad y=-0,0926 x^{2}+0,2333 x+86,6 R^{2}=97$

Dose $100 y=-0,1349 x^{2}+0,7190 x+91,50 R^{2}=99$

$\triangle$ Dose $200 y=-0,0635 x^{2}+0,2063 x+91,72 R^{2}=99$

Dose $300 \quad y=-0,7 x+96 R^{2}=98$

WDose $400 \quad y=-0,7333 x+95,07 R^{2}=96$

Dose $500 \quad y=-0,0741 x^{2}+0,155+79,9 R^{2}=94$ 

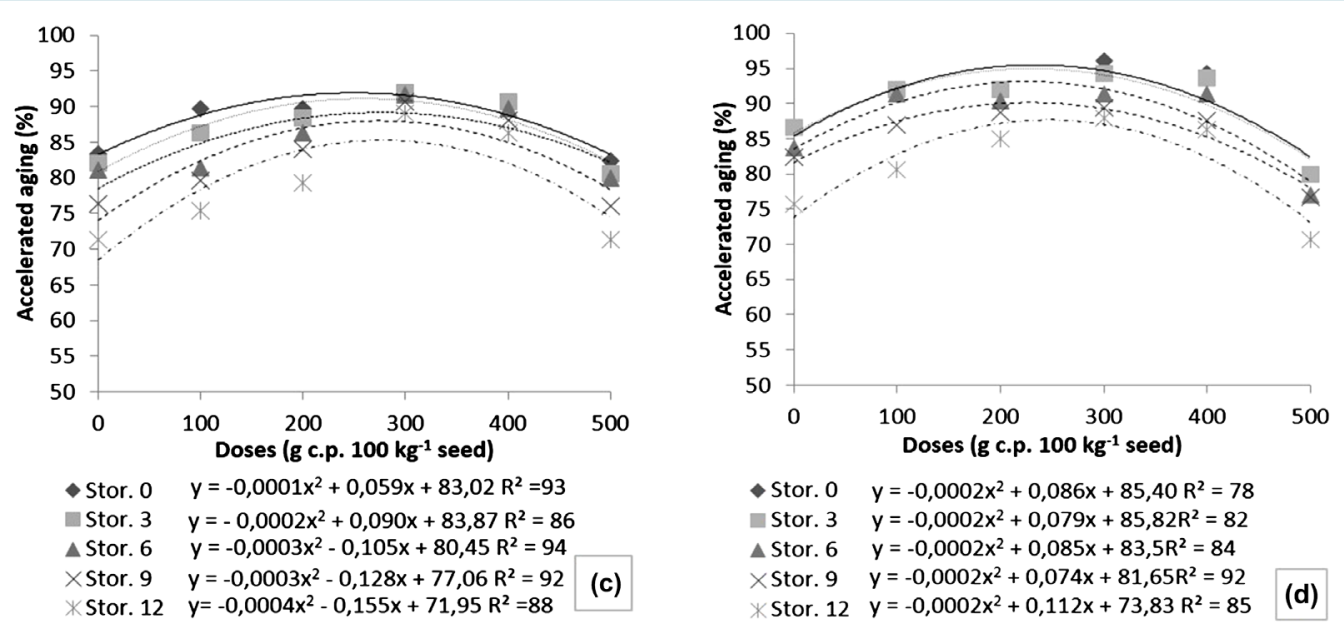

Figure 3. (a) Accelerated aging test (EA) of rice seeds, cultivar INIA Olimar treated to different doses of thiamethoxam; (b) EA for rice seeds from cultivar El Paso L144, treated to different doses of thiamethoxam; (c) EA rice seeds from cultivar INIA Olimar, under different storage periods; and (d) EA rice seeds from cultivar El Paso L144 under different storage periods. Pelotas, RS, 2014.
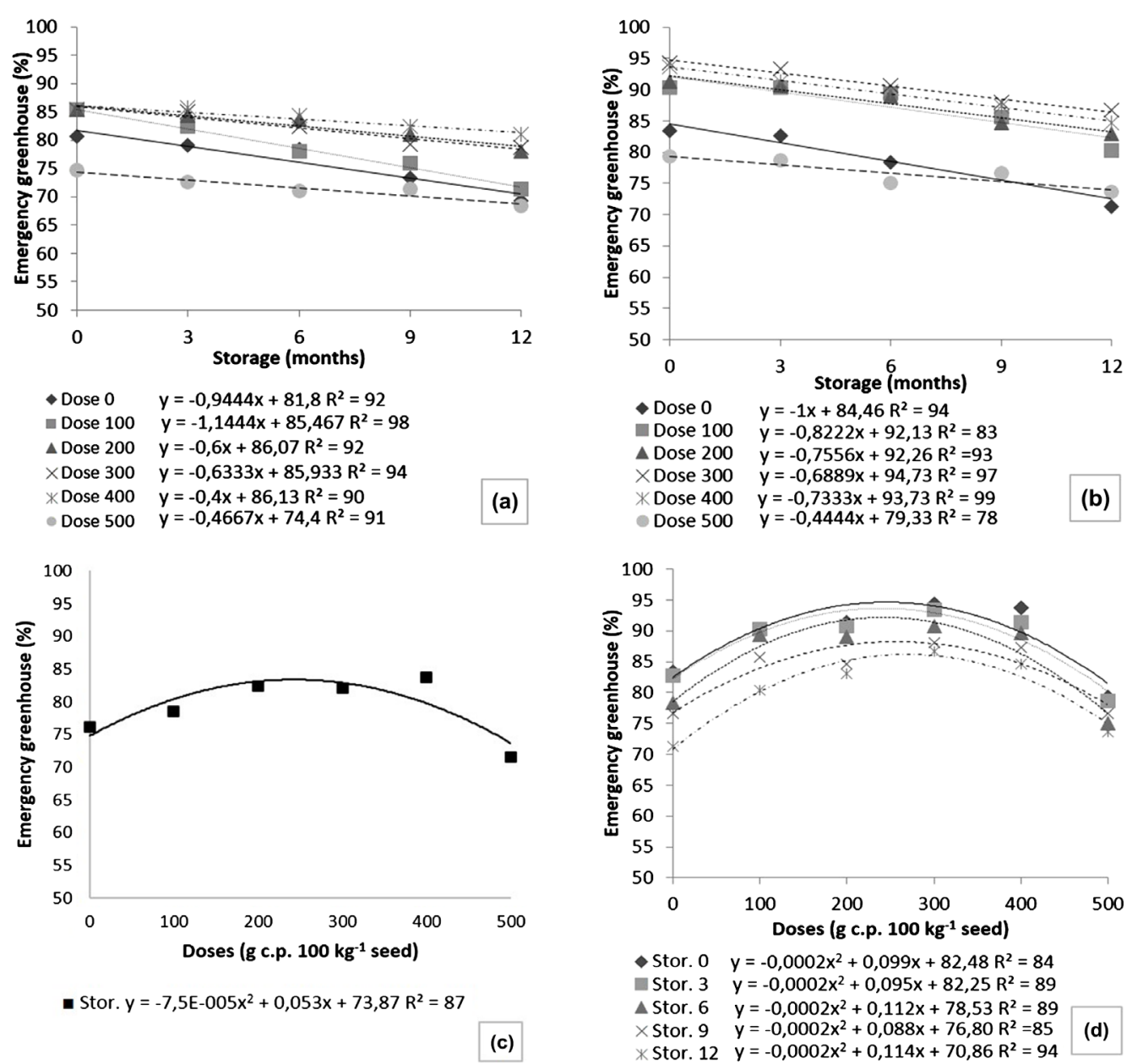

Figure 4. (a) Seedling emergence in the glasshouse (ECV) of rice seeds, cultivar INIA Olimar treated with different doses of thiamethoxam; (b) ECV for rice seeds from cultivar El Paso L144, treated with different doses of thiamethoxam; (c) ECV rice seeds from cultivar INIA Olimar, under different storage periods; and (d) ECV rice seeds from cultivar El Paso L144 under different storage periods. Pelotas, RS, 2014. 
Generally speaking, the tests performed on both rice cultivars used on this study show that thiamethoxam had a similar positive effect on germination and seed vigor, and that the highest values for seed quality were achieved at thiamethoxam doses between $200 \mathrm{~g}$ and $400 \mathrm{~g}$ per hundred kilograms of seed.

\section{Conclusion}

Treatment with thiamethoxam of rice seeds from cultivars INIA Olimar and El Paso L144, prior to storage, at doses of $200 \mathrm{~g}$ to $400 \mathrm{~g}$ active ingredient per $100 \mathrm{~kg}$ of seeds yielded the highest values for germination and seed vigor.

\section{References}

[1] CONAB - Companhia Nacional de Abastecimento (2014) Acompanhamento de safra brasileira: Grãos, sexto levantamento, março 2014. Companhia Nacional de Abastecimento. Conab, Brasília, 11-12. http://www.conab.gov.br/OlalaCMS/uploads/arquivos/14_03_12_08_41_24_boletim_graos_marco_2014.pdf

[2] Oliveira, S. (2013) Tratamento de Sementes: Ferramenta Promissora e Eficiente para o Agricultor. Seed News, XVII, 8-11.

[3] Calafiori, M.H. and Barbieri, A.A. (2001) Effects of Seed Treatment with Inseticide on the Germination, Nutrients, Nodulation, Yield and Pest Control in Bean (Phaseolus vulgaris L.) Culture. Ecossistema, 26, 97-104. file:///C:/Users/cris/Downloads/ECO-2006-23.pdf

[4] Almeida, A.S., Carvalho, I., Deuner, C., Tilmann, M.A.A. and Villela, F.A. (2011) Bioativador no desempenho fisiológico de sementes de arroz. Revista Brasileira de Sementes, 33, 501-510. http://dx.doi.org/10.1590/S0101-31222011000300013.

[5] Castro, P.R.C., Pitelli, A.M.C.M., Peres, L.E.P. and Aramaki, P.H. (2007) Análise da atividade reguladora de crescimento vegetal de tiametoxam através de biotestes. Publicatio, 13, 25-29. http://www.revistas2.uepg.br/index.php/exatas/article/viewFile/892/774

[6] Antonello, L.M., Muniz, M.B., Brand, S.C., Vidal, M.D., Garcia, D., Ribeiro, L. and Santos, V. (2009) Qualidade de sementes de milho armazenadas em diferentes embalagens. Ciência Rural, 39, 2191-2194. http://dx.doi.org/10.1590/S0103-84782009005000157

[7] Teló, G.M., Marchesan, E., Ferreira, R.B., Menezes, N.L., Hansel, D.S.S. and Sartori, G.M.S. (2012) Aplicação de fungicida em plantas de arroz irrigado e seu efeito na qualidade de sementes durante o armazenamento. Revista Brasileira de Sementes, 34, 156-163.

http://www.scielo.br/scielo.php?script=sci_arttext\&pid=S0101-31222012000100019 http://dx.doi.org/10.1590/S0101-31222012000100019

[8] Brasil (2009) Ministério da Agricultura e Reforma Agrária. Regras para análise de sementes. http://www.agricultura.gov.br/images/MAPA/arquivos portal/ACS/sementes web.pdf

[9] Cícero, S.M. and Vieira, R.D. (1994) Teste de frio. In: Vieira, R.D. and Carvalho, N.M., Eds., Testes de vigor em sementes, FUNEP, Jaboticabal, 151-164.

[10] McDonald Jr., M.B. and Phaneendranath, B.R. (1978) A Modified Accelerated Aging Vigor Test Procedure. Journal of Seed Technology, 3, 27-37. http://www.scielo.br/scielo.php?script=sci_nlinks\&ref=000116\&pid=S0101-3122201100030001300013\&lng=en

[11] Laposta, J.A. (1991) Comparação entre métodos para avaliação da qualidade fisiológica de sementes de algodão (Gossypium hirsutum L.). Dissertação (Mestrado em Agronomia—Fitotecnia)—Escola Superior de Agricultura de Lavras, 61f.

[12] Machado, A.deA. and Conceição, A.R. (2003) WinStat: Sistema de análise estatística para Windows. Versão 2.0, UFPEL/NIA, Pelotas. http://www.scielo.br/scielo.php?script=sci_nlinks\&ref=000101\&pid=S0101-3122201000020000100016\&lng=en

[13] Canteri, M.G., Althaus, R.A., Virgens Filho, J.S., Giglioti, E.A. and Godoi, C.V. (2001) SASM-Agri: Sistema para análise e separação de médias em experimentos agrícolas pelos métodos Skott-Knott, Tukey e Duncan. Revista Brasileira de Agrocomputação, 1, 18-24. http://www.agrocomputacao.deinfo.uepg.br/dezembro_2001/Arquivos/RBAC_Artigo_03.pdf

[14] Almeida, A.S., Tillmann, M.A.A., Villela, F.A. and Pinho, M.S. (2009) Bioativador no desempenho fisiológico de sementes de cenoura. Revista Brasileira de Sementes, 31, 87-95. http://www.scielo.br/pdf/rbs/v31n3/a10v31n3.pdf

[15] Tavares, S., Castro, P.R.C., Ribeiro, R.V. and Aramaki, P.H. (2007) Avaliação dos efeitos fisiológicos de tiametoxam no tratamento de sementes de soja. Revista de Agricultura, 82, 47-54. 
http://www.scielo.br/scielo.php?script=sci_nlinks\&ref=000132\&pid=S0101-3122200900030001000013\&lng=en

[16] Clavijo, J. (2008) Tiametoxam: Um nuevo concepto em vigor y productividad. Editora Vozes, 196 p.

[17] Lauxen, L.R., Villela, F.A. and Soares, R.C. (2010) Desempenho fisiológico de sementes de algodoeiro tratadas com thiamethoxam. Revista Brasileira de Sementes, 32, 61-68. http://dx.doi.org/10.1590/S0101-31222010000300007

[18] Brasil (2005) Padrões para produção e comercialização de sementes de soja. http://www.agricultura.pr.gov.br/arquivos/File/PDF/padroes_soja.pdf

[19] Marcos Filho, J. (2005) Fisiologia de sementes de plantas cultivadas. FEALQ, Piracicaba, 495 p. http://www.scielo.br/scielo.php?script=sci_nlinks\&ref=000114\&pid=S0101-3122201100030001300012\&lng=en

[20] Almeida, A.S., Villela, F.A., Meneghello, G.E., Lauxen, L.R. and Deuner, C. (2012) Desempenho fisiológico de sementes de aveia-preta tratadas com thiamethoxam. Semina: Ciências Agrárias, 33, 1619-1628. http://www.uel.br/revistas/uel/index.php/semagrarias/article/viewFile/7502/11541 http://dx.doi.org/10.5433/1679-0359.2012v33n5p1619

[21] Grisi, P.U., Santos, C.M., Fernandes, J.J. and Sá Júnior, A. (2009) Qualidade das sementes de girassol tratadas com inseticidas e fungicidas. Bioscience Journal, 25, 28-36. http://www.scielo.br/scielo.php?script=sci_nlinks\&ref=000119\&pid=S0101-3122201000020001600015\&lng=en

[22] Almeida, A.S., Villela, F.A., Meneghello, G.E., Jauer, A. and Nunes, J.C. (2013) Thiamethoxam: An Inseticide that Improve Seed Rice Germination at Low Temperature. In: Insecticides-Development of Safer and More Effective Technologies, InTec, 417-426. http://dx.doi.org/10.5772/53207

[23] Soares, V.N., Tilmann, M.A.A., Moura, A.B. and Zanatta, Z.G.C.N. (2012) Physiological Potential of Rice Seeds Treated with Rhizobacteria or the Insecticide Thiamethoxam. Revista Brasileira de Sementes, 34, 561-572. http://dx.doi.org/10.1590/S0101-31222012000400006 
Scientific Research Publishing (SCIRP) is one of the largest Open Access journal publishers. It is currently publishing more than 200 open access, online, peer-reviewed journals covering a wide range of academic disciplines. SCIRP serves the worldwide academic communities and contributes to the progress and application of science with its publication.

Other selected journals from SCIRP are listed as below. Submit your manuscript to us via either submit@scirp.org or Online Submission Portal.
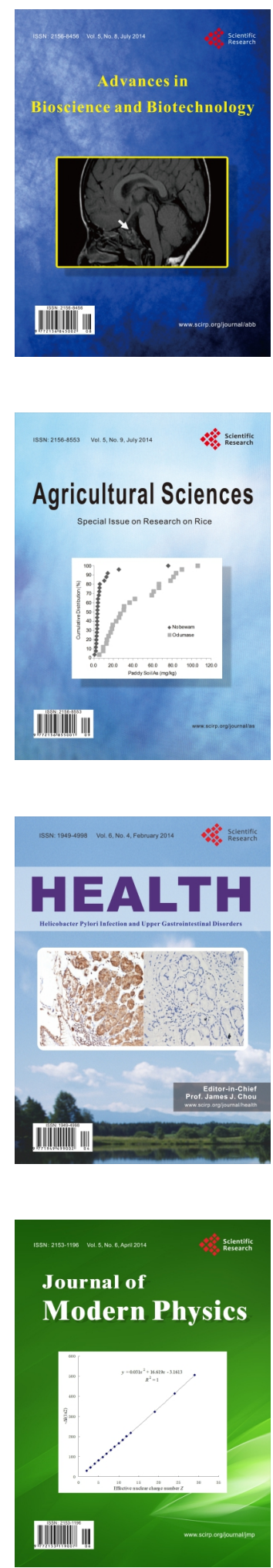
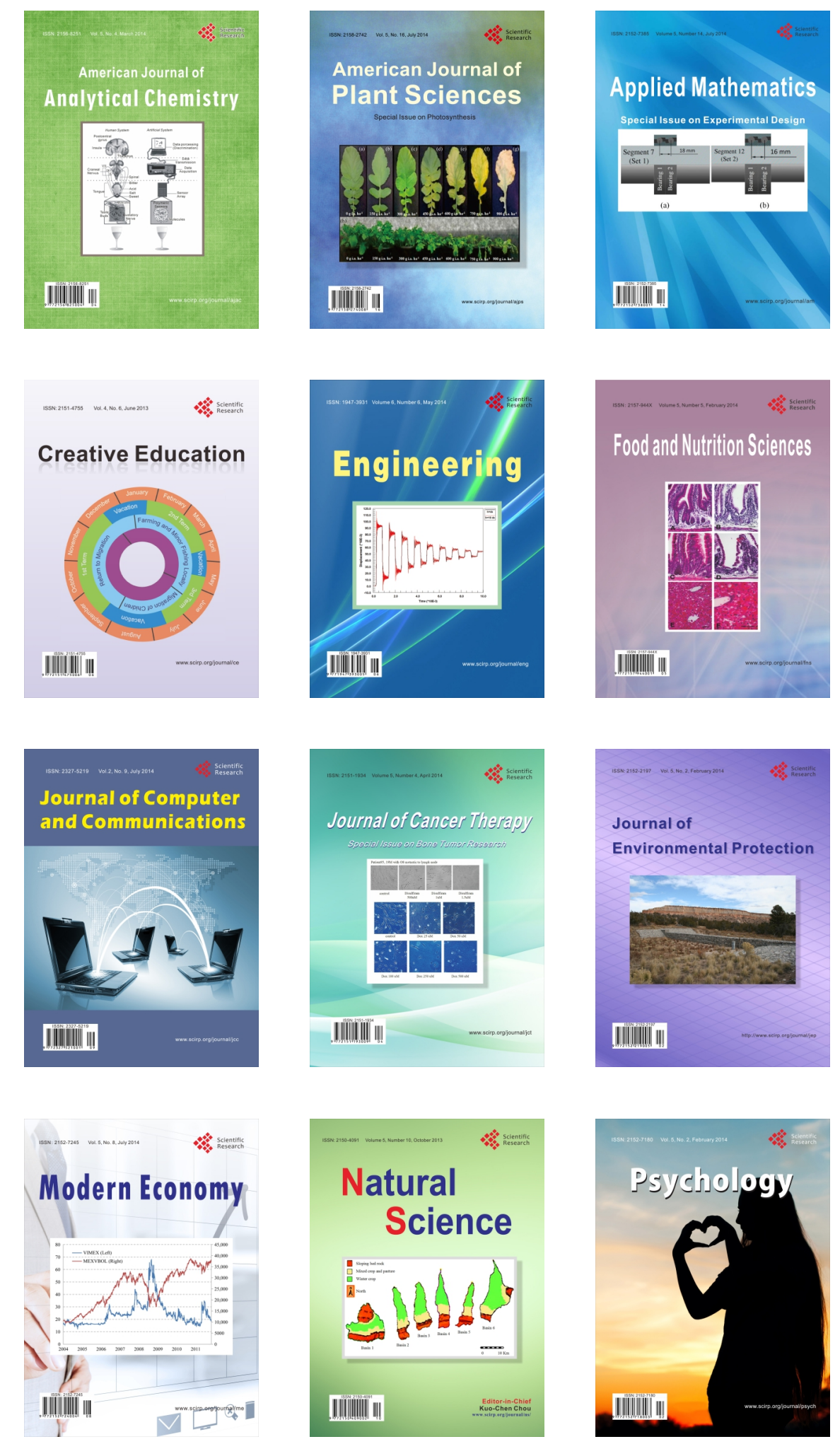